Ankara Üniversitesi Türk İnkllâp Tarihi Enstitüsü Atatürk Yolu Dergisi S 35-36, Mayıs-Kasim 2005, s. 431-434

\title{
Atatürk'ün Kartvizitleri
}

\author{
Doç. Dr. Oğuz AYTEPE*
}

Türkiye Cumhuriyeti'nin kurucusu büyük önder Mustafa Kemal Atatürk'ün kullandığı kartvizitleri ile ilgili yaptığımız araştırma Türk İnkılâp Tarihi Enstitüsü Arşivi'nde (T.İ.T.E. A.) dört, Anıtkabir, Atatürk ve Kurtuluş Savaşı Arşivi'nde bir olmak üzere beş kartvizit tespit ettik. Ekte örnekleri gösterilen kartvizitlerden 1,2, 3 ve 5 numaralı olanlar Enstitümüz Arşivi'nde $^{1} 4$ numaralı olan ise Anıtkabir, Atatürk ve Kurtuluş Savaşı Arşivi'nde ${ }^{2}$ bulunmaktadır.

Arşivimizde bulunan kartvizitlerin tamamı Atatürk'ün yakın arkadaşlarından Behiç Erkin Bey'in arşivimize bağışladığı belgeler arasında yer almaktadır. Kartvizitlerden bir numaralı olanın arkasında 2.12 .33 (2.12. 1333/1917) tarihinde Mustafa Kemal'in Behiç Bey'e verdiğini belirten bir yazı vardır. Diğerlerinde herhangi bir yazı ve tarih yoktur.

• Ankara Üniversitesi Türk İnkılâp Tarihi Enstitüsü, Öğretim Üyesi.

' TİTEA, Kutu No. 162, Gömlek No. 1, Belge No. 1-(9), 129 / 20224; 1-(2) 129 / 20225; 1-(8) 129/20223; 1-(5) 129 / 2022/a.

Anıtkabir Atatürk ve Kurtuluş Savaşı Arşivi, Belge No. 1035 / 14. 
ATATÜRK'ÜN KARTVIZITLLERI

433

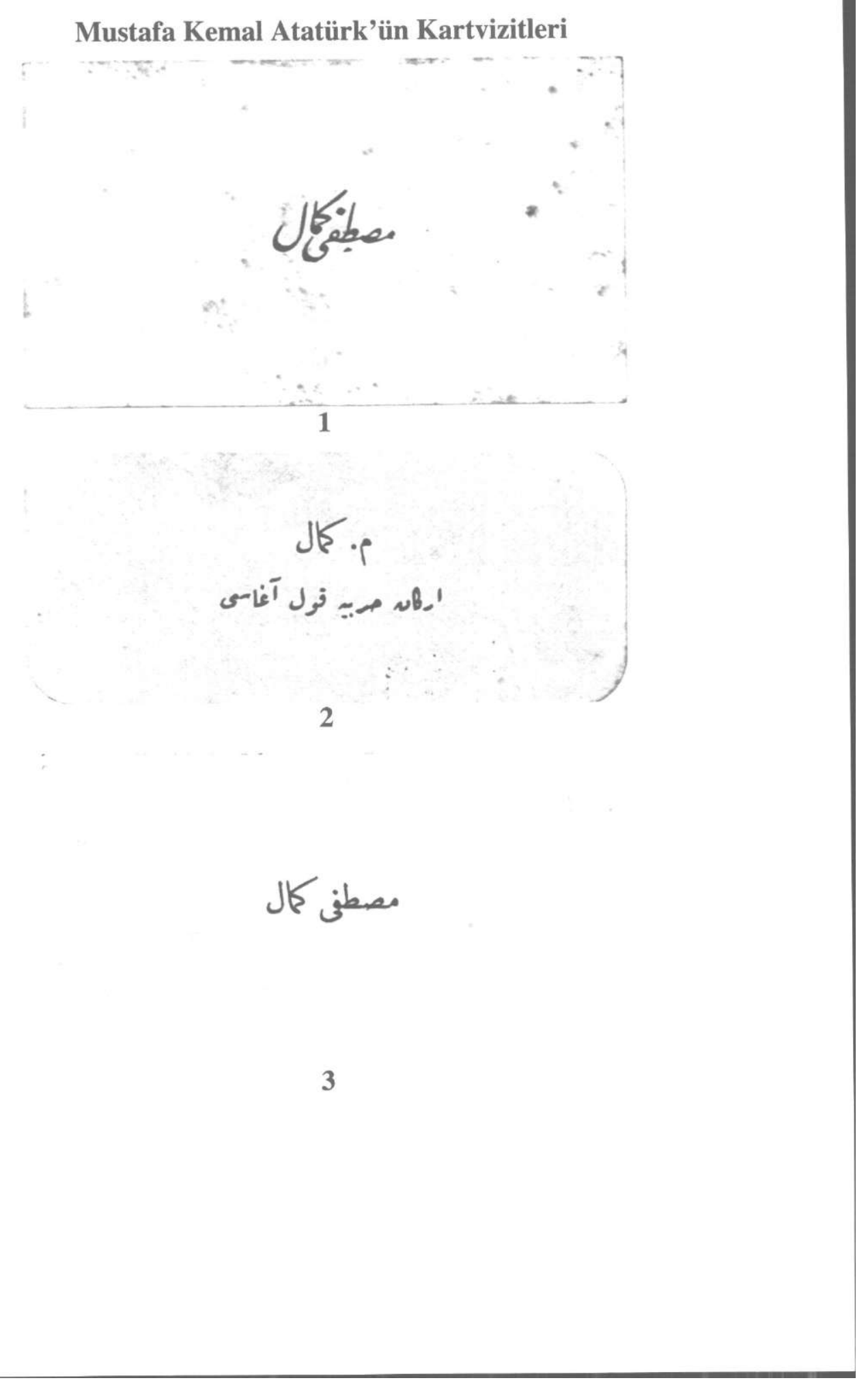


Mustafa Kemal Atatürk'ün Kartvizitleri.

4

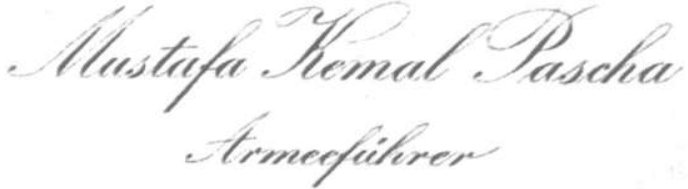

5 
Ankara Üniversitesi Türk Inkılâp Tarihi Enstitüsü Atatürk Yolu Dergisi S 35-36, Mayı-Kasım 2005, s. 435-458

\section{Mustafa Kemal Paşa Tarafından Ali Fuad Paşaya}

Gönderilen Bazı Telgraf, Tebliğ ve Yazışmalar-(II)

Mustafa TOKER*

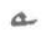

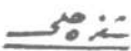

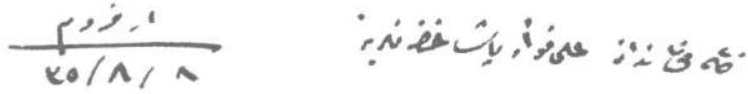

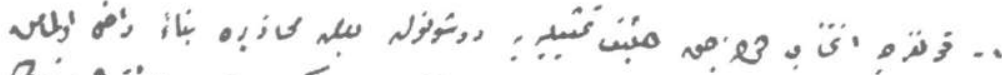

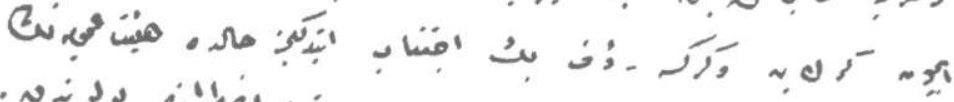

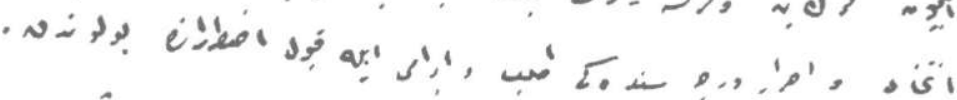

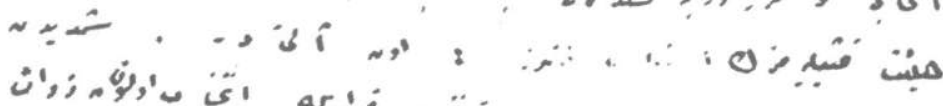

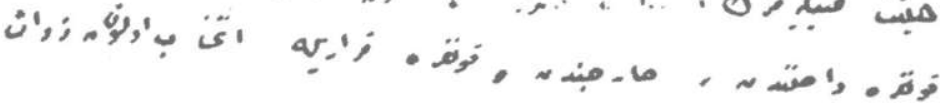

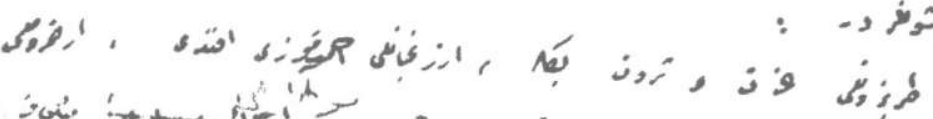

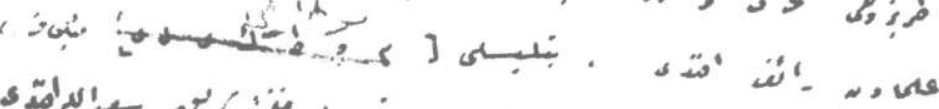

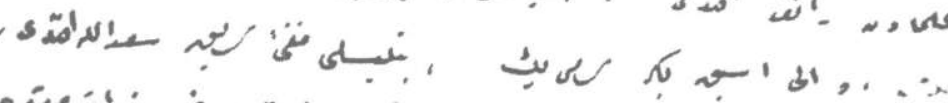

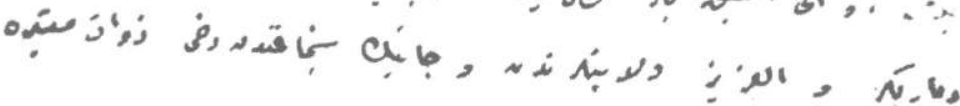

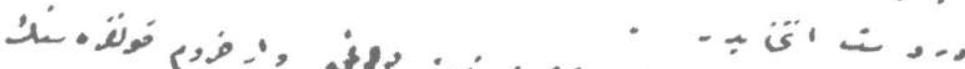

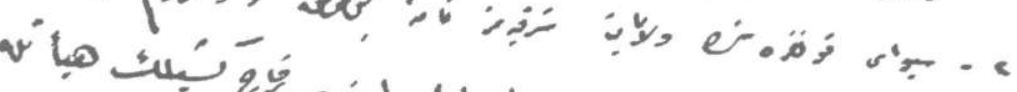
-

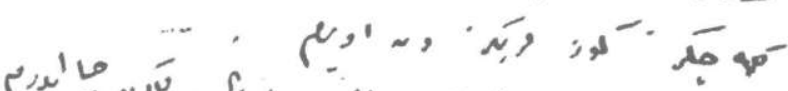

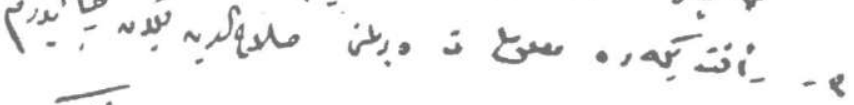
$\Omega$ ise

• Ankara Üniversitesi Türk İnkılâp Tarihi Enstitüsü Uzmanı. 
Şifre hâlli

\section{K. Kumandanı 'Alî Fû'âd Pâsâ Hazretlerine}

1-Kongrece intihâb olunacak hey'et-i temsîliyeye düsünülen ba'zl mahâzîre binâ'en dahîl olmamak için gerek ben ve gerekse Ra'ûf Bey ictinâb ettiğimiz hâlde hey'et-i 'umûmîyenin intihâbı ve usrar derecesindeki taleb ve ibrâmı ile kabûl-i ıztırârında bulunduk. Hey'et-i temsîliyemizin a'zâsı dokuz : on altıdır. Şimdiden kongre dâhilinden, hâriçinden ve kongre kararıyla intihâb olunan zevât şunlardır:

Trabzonlu 'izzet ve Servet Beyler, Erzincânll Âhmed Fevzi Efendi, Erzurumlu 'ulemâdan Raif Efendi, Bitlisli Mutkulu Hâcı Mûsâ Bey, Vâlî-i Esbak Bekîr Sâmî Bey, Bitlisli Müfti-i Sâbık Sa'dullah Efendi, Diyârbekir ve El-'Azîz vilâyetlerinden ve Cânîk Sancă̆ı'ndan dahî zevât-ı mu'tebere derdest-i intihâbdır.

2-Sivâs Kongresi'nde vilâyât-ı şarkîyemiz nâmına bulunmak ve Erzurum Kongresi'nin mukarrerâtını resmen teblîğe selâhiyetdâr olmak üzere birkaç kişilik hey`etle geleceğiz. Gözlerinizden öperim.

3-Re`fet Beye de ma'lûmât verilmesini Selâhad-dîn Beyden ricâ ederim.

Mustafâ Kemâl

\footnotetext{
${ }^{1}$ TİTE Arşivi, Kutu No:299, Gömlek No:19, Belge No:19.
} 
MUSTAFA KEMAL PAŞA TARAFINDAN ALI FUAD PAŞAYA.....

437

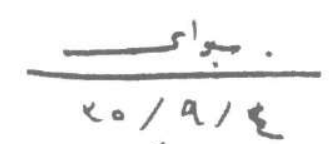

تن

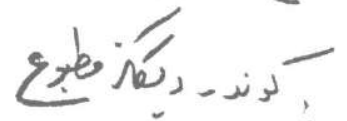

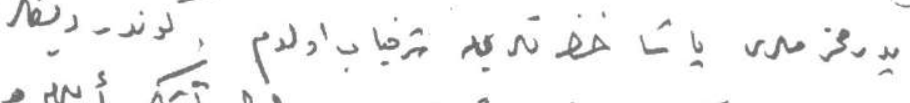

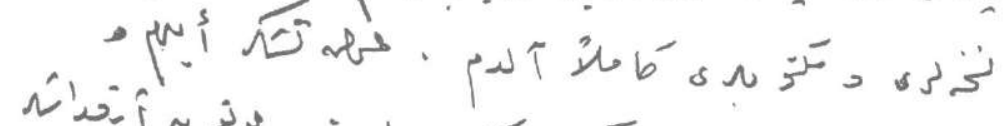

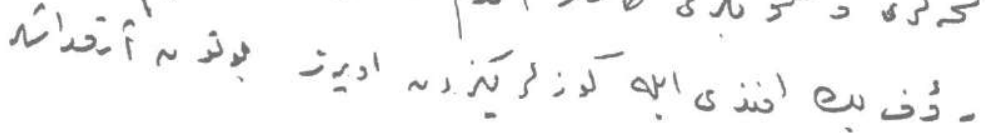

unîue

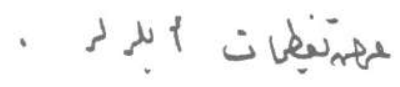

$2 / 3$

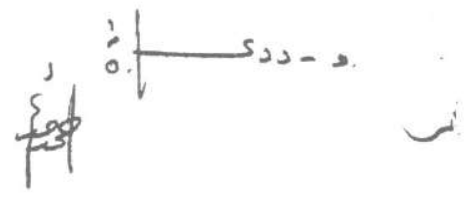


Şifre hâlli

Ankara 20. K. Kumandanlı̆̆ına

Peder-i muhteremleri pâşâ hazretleriyle şeref-yâb oldum. Gönderdiğiniz matbû' nüshaları ve mektûbları kâmilen aldım. 'Arz-ı teşekkür eylerim.

Ra'ûf Beyefendi ile gözlerinizden öperiz bütün arkadaşlar 'arz-l ta'zîmât eylerler.

Vürûdu 5 minh

Numro 77

Mustafâ Kemâl ${ }^{2}$

${ }^{2}$ TİTE Arşivi, Kutu No:302, Gömlek No:64, Belge No:64. 


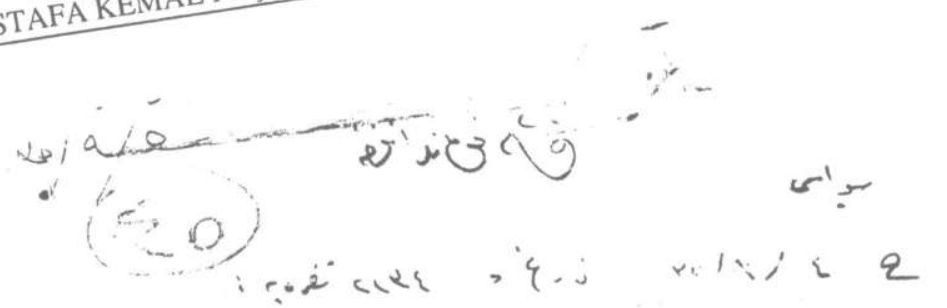

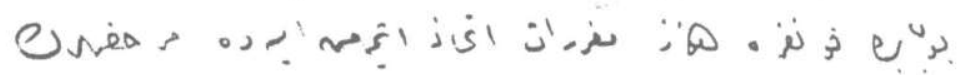

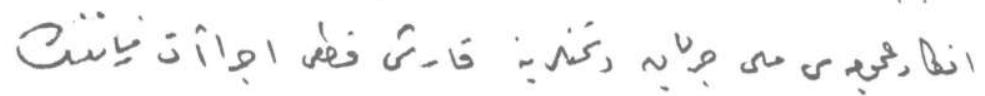

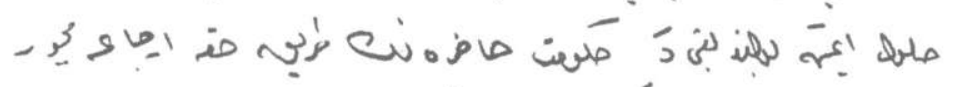
البدل

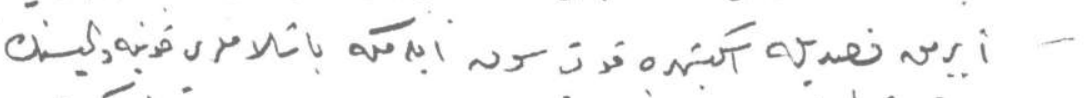

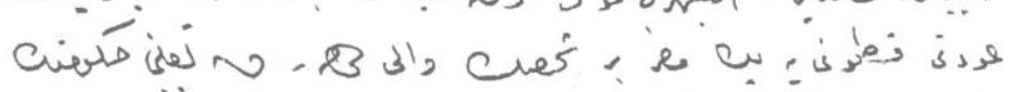

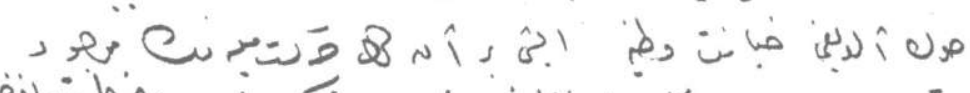
نे

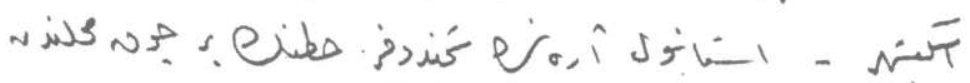

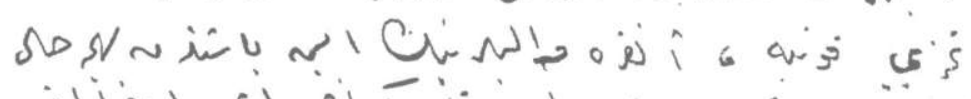
ذال

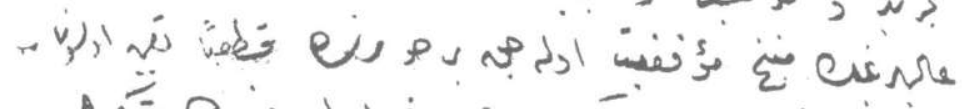

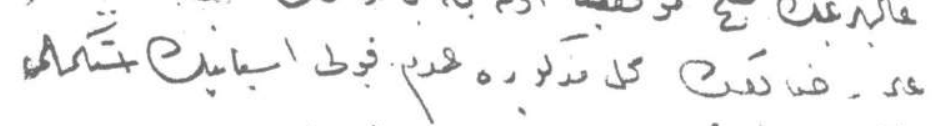

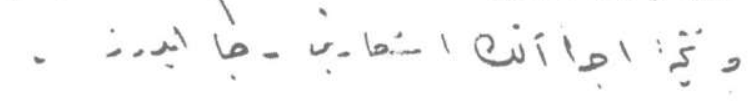
约 
440

MUSTAFA TOKER

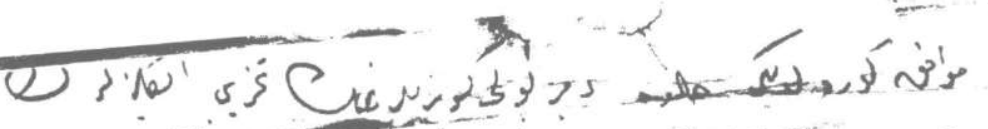

술

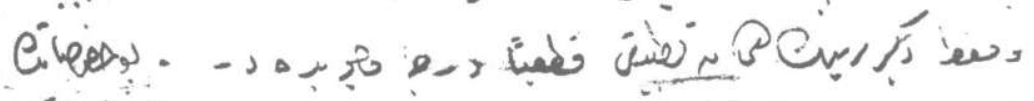

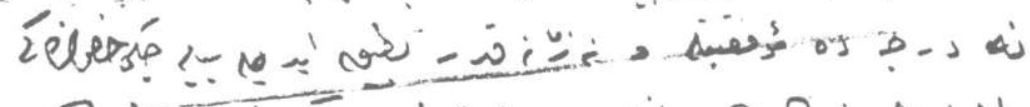

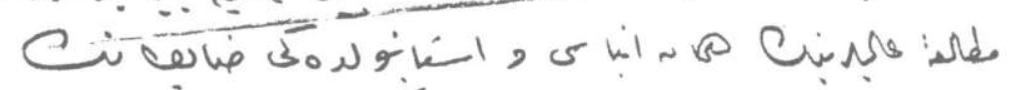

ص'

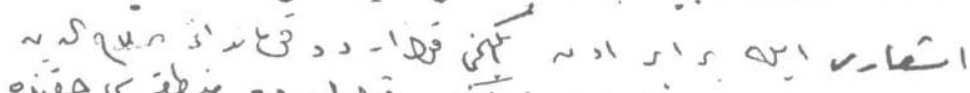

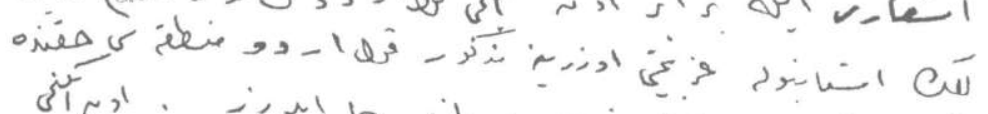

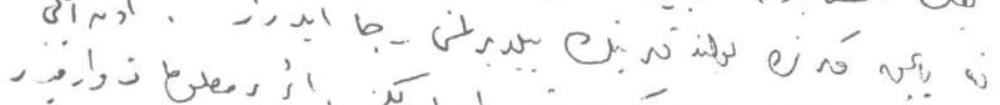

קه

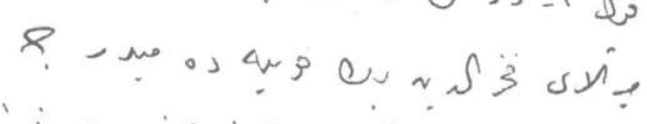

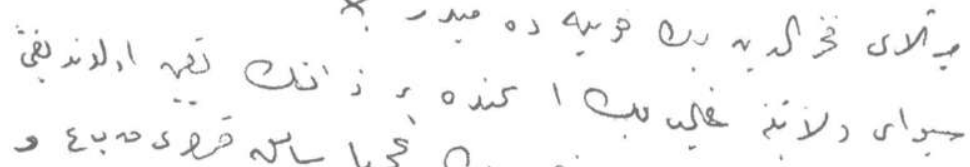

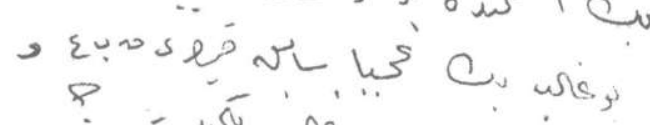

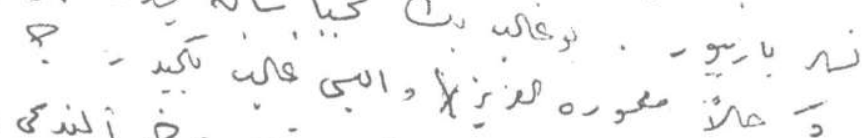

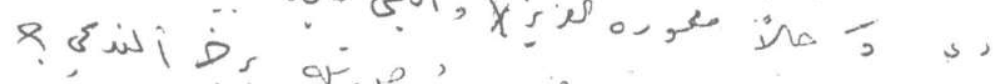

$$
\text { هـ }
$$




\section{K. Kumandanlı̆̆ına}

C. 4/9/35 târîh ve 2134 şifrey:

Bu bâbda kongre henüz mukarrerât ittihâz etmemiş ise de murahhasların efkâr-l 'umûmîyesi millî cereyân düşmânlarına karşı kat'̂̂ icrâât zamânının hulûl etmiş bulunduğu ve hükûmet-i hâzıranın tarîk-i hakka ircâ'a mecbûr edilmesi esâslarında temerküz ediyor. Ingilizlerin şarkî ve garbî Anadolu'yu ayırmak kasdıyla Eskişehir'e kuvvet sevk eylemeğe başlamaları Konya vâlîsinin 'avdeti Kastamonu'ya pek muzır bir şahsın vâlî olarak ta'yîni hükûmetin son aldı̆̆ l hryânet-i vataniye işi bir an evvel hareket-i milliyenin mevcûd ve kahhâr olduğunu düşmânlarımız nazarında isbât etmeğe bizi muztarr kıldığından Eskişehir-İstânbûl arasında şimendûfer hattının bir çok mahâllinden tahribi Konya, Ankara vâlîlerinin iş başından behe-ma-hâl tecrîd ve tevkîf ve teb 'îdleri hakkındaki tasavvurât ve ihzârât-l 'âlîlerinin ..... muvaffaklyyet olacak bir sûrette kat'iyen ta'yîn olunan 'Alî Rızâ Beyin mahal-i mezkûre 'adem-i kabûlü esbâbının istikmâlî ve netice-i icrââtın iş ârını ricâ ederiz.

Muvâfik görüldüğ̈̈ hâlde demiryolu köprülerinin tahribi Ingilizlerin 'asker sevkine başladıklarının anlaşılması zamânına kadar te hîr olunabilir. Ve fakat diğerlerinin hemân tatbîk̂े kat'iyen derece-i vücûbdadır. Bu husûsâtın ne derecede muvaffaklyyetle ve ne zamâna kadar tatbîk edilebilecĕ̆ $i$ husûsundaki mütâla'a-i 'âlîlerinin hemân inbâsı ve İstânbûl'daki zâbitânın harekâtı hakkında verilen haberlere müte'allik yeni ma 'lûmât var ise onların da iş'ârı ile berâber Onikinci. Kolordu Kumandanı Selâhad-dîn Beyin İstânbûl'a 'azîmeti üzerine mezkûr kolordu mintıkast hakkında ne yapmak fikrinde bulunduklarının bildirilmesini ricâ ederiz. OnikinciKolordu kumandanlı̆̆ına kimin ta'yîn edildiğine dâ'ir bir ma'lûmât var mıdır? Mîrâlây Fahreddîn Bey Konya'da mıdır?

Sivâs Vilâyetine Gâlîb Bey isminde bir zâtın ta'yîn olduğunu ajanslar yazıyor. Bu Gâlîb Bey 'acebâ sâbık Kayserî $k b a v d y$ ve hâlen Ma'mûretü'l- 'Azîz Vâlîsi Gâlîb Bey midir? Buna dâ'ir gazetelerden ve yahûd sâ'ir sûretle bir haber alındı mi? Cevâb-l 'âlilerine şimdi intizâr eder ve tahassürle gözlerinizden öperiz.

Mustafâ Kemâl ${ }^{3}$

\footnotetext{
${ }^{3}$ TİTE Arşivi, Kutu No:302, Gömlek No:56, Belge No:56, 56-1.
} 
442

MUSTAFA TOKER

$\frac{5}{50 / q a}$ is

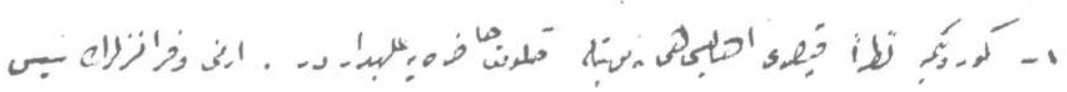

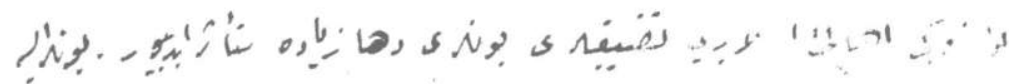

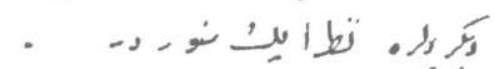

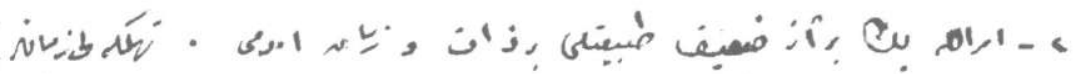

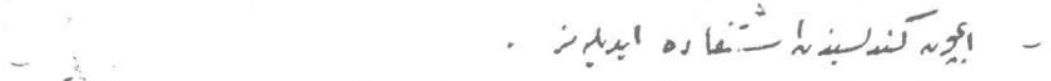

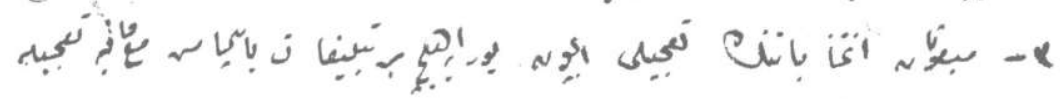

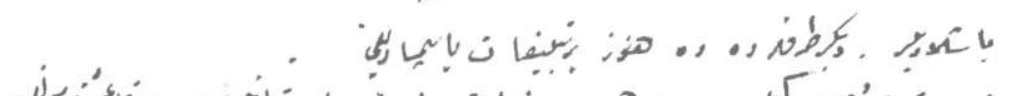

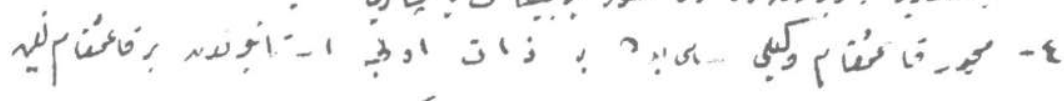

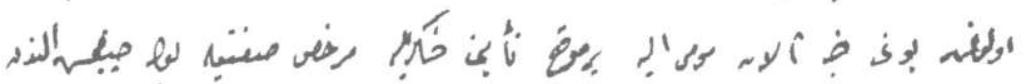

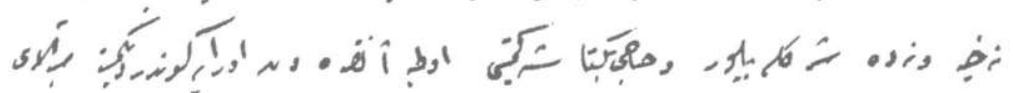

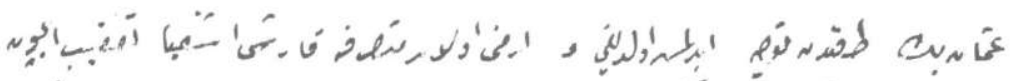

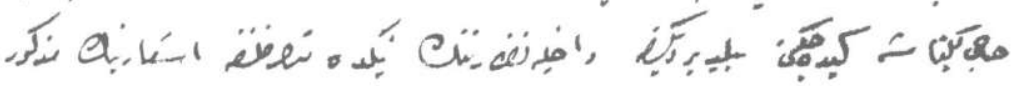

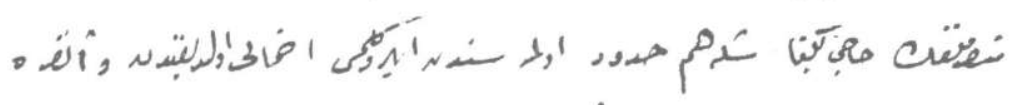

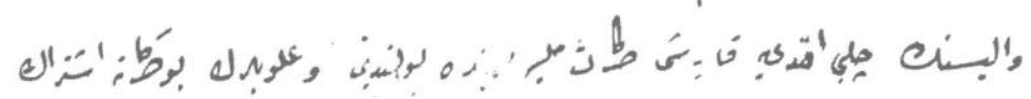

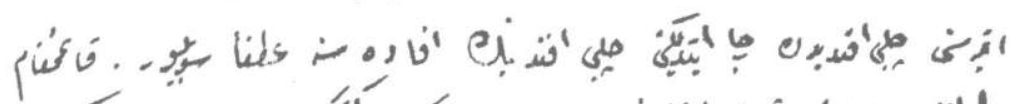

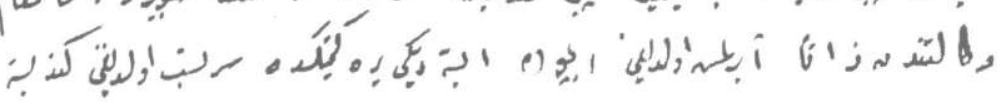

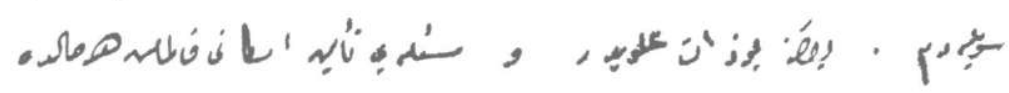




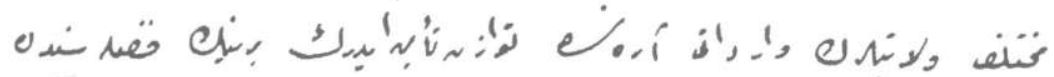

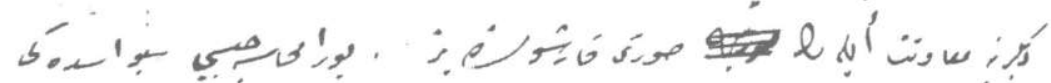

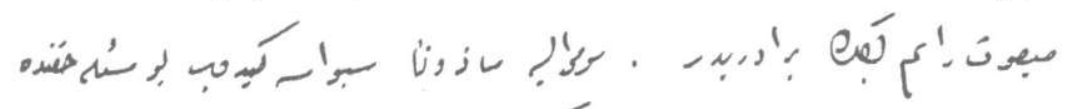

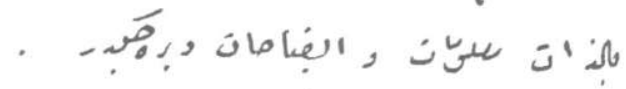

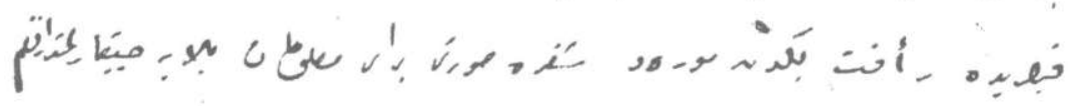

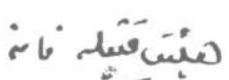

$$
\begin{aligned}
& \text { colifier } \\
& \therefore \text {. o.f }
\end{aligned}
$$


Şifre Hâlli

Ankara: 20. K. Kumandanlığına

1- Gördüğüme nazaran Kayserî âhâlîsi hemân 'umûmîyetle hükûmet-i hâzıraya 'aleyhdârdır. Ermenî ve Fransızların Sîs Livâsı'ndaki âhâlî-i İslâmiyeyi tazyîkleri bunlarl daha ziyâde müte`essir ediyor. Bunlar ise diğerlere nazaran pek münevverdir.

2- Emrullah Bey birâz za'îf tabî'atlı bir zât ü zemân adamı. Tehlikeli zamânlar için kendisinden istîfâde edilemez.

3- Meb ûsân intihâbâtının ta'cîlî için buraya hiçbir tebligât yapılmamış ma'-mâfih ta'cîle başladılar. Dĭ̆er taraflarda da henüz bir tebligât yapılmadı $\breve{g l}$.

4- Mucur Kâ'imakâm Vekili Sâmî Bey bir zât evvelce İstânbûl'dan bir kaimakâm ta'yîn olunmuş bunu haber alan mûmâ-ileyh bir mevki' te'mîni fikriyle murahhas sifatıyla yola çıkmış elinden ne hayr ve ne de şer gelebiliyor. Ve Hâcıbektâş'a gitmesi evvelce Ankara'dan oraya gönderdiğimiz Mîrâlây 'Osmân Bey tarafindan tavsiye edilmiş olduğu ve Ermenî olan mutasarrıfa karşı eşkıyâ ta'kîb için Hâcıbektâş'a gideceğini bildirdiğinden Dâhiliye Nezâretinin Niğde Mutasarrıflı̆̆ına iş'ârının mezkûr mutasarrıflı̆̆ın Hâcıbektâş̧a hem hudûd olmasından ileri gelmesi ihtimâlî olduğundan ve Ankara vâlîsinin Çelebî Efendiye karşı harekât-ı milliye 'aleyhinde bulunduğu ve 'Alevîlerin bu harekâta iştirâk etmemesini Çelebî̀ Efendiden ricâ ettiğini Çeleb̂े Efendi'nin îfâdesine 'atfen söylüyor. Kâ`imakâm vekâletinden zaten ayrılmış olduğu için istediği yere gitmekte serbest olduğunu kendisine söyledim. Yalnız bu zât 'Alevîdir ve mes'eleyi te 'mîn imkânı kalmamış her hâlde muhtelif vilâyetlerin vâridâtı arasında tevâzün te'mîn ederek birinin fazlasindan diğerine mu'âvenet eylemek sûreti karşısındayız. Bura muhâsebecisi Sivâs'daki Meb'ûs Râsim Beyin birâderidir. Mûmâ-ileyh me`zûnen Sivâs'a gidib bu mes'ele hakkında bizzât ma'lûmât ve îzâhât verecektir.

Kayserî'de Re`fet Beyden mevrûd şifre sûreti berâ-yı ma'lûmât bâlâya çıkarılmıştır. Efendim.

Cevap verilmiştir.

Hifz / 23 minh

Hey'et-i Temsîle Nâmına

Mustafâ Kemâl ${ }^{4}$

${ }^{4}$ TITE Arşivi, Kutu No:306, Gömlek No:1, Belge No:1. 


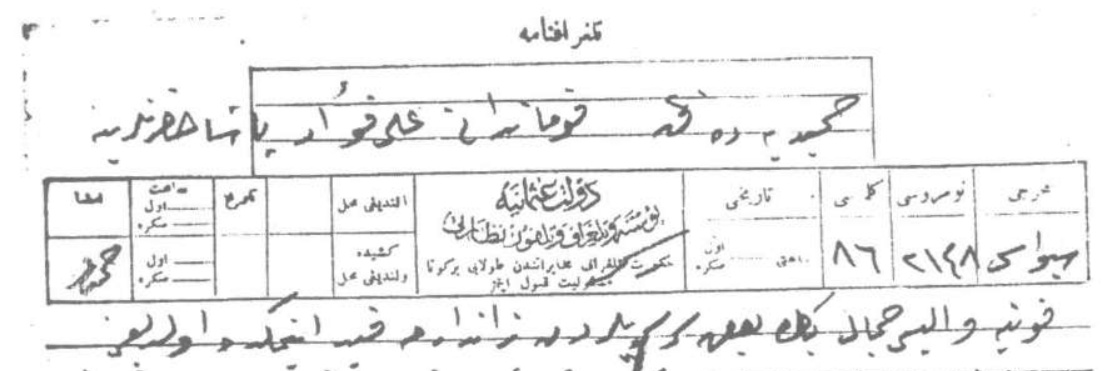

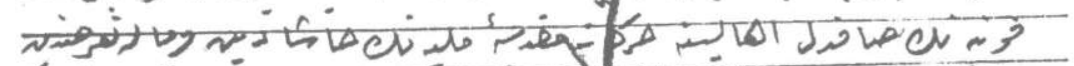

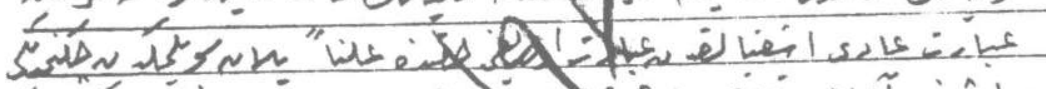

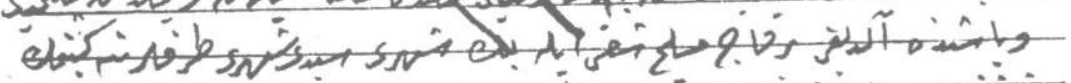

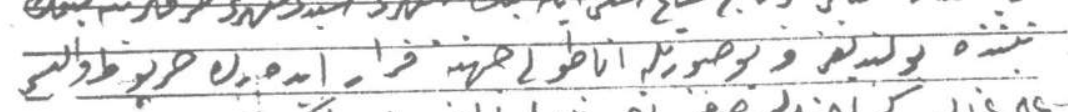

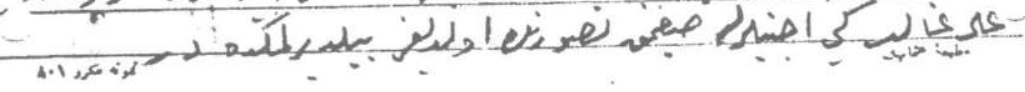

$$
\text { كs }
$$

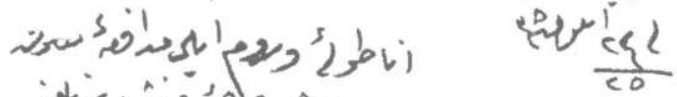
irtins

Paser

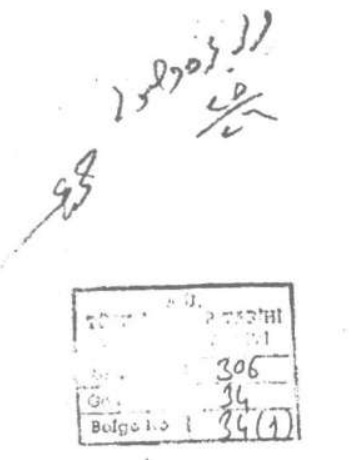

$114 / 5-2705$ 


\section{Telgrâfnâme}

Mahreci: Sivâs

Numrosu: 2148

Hamîdiye'de 20. K. Kumandanı 'Alî Fû âd Pâşâ Hazretlerine

Konya Vâlisi Cemâl Beyin ba'zl serserilerden jândârma kayd etmekte olduğu Konya'nın sâf-dil âhâlîsine harekât-ı mukaddese-i milliyenin hâşâ dîn ve mala ta'arruzdan 'ibâret 'âdî eşkıyâlıktan 'ibâret olduğu hakkında 'alenen yalan söylemekten çekinmediği ve başında(?) aldlğı birkaç müsellah şakî ile Beyşehrî Seydîşehrî taraflarına gitmek niyetinde bulunduğu ve bu sûretle Anadolu cihetine firâr ederk Harpût Vâlîsi 'Alî Gâlîb gibi ecnebilerle sığınmak tasavvurunda olduğu bildirilmektedir.

Keyfiyetin tahkîk ve iş'ârı ve tedâbîr-i kanûnun ittihâzı 'arz olunur.

24/25 Eylül 35

Merkezimize vusûlü 25/26

Anadolu ve Rûmeli Müdâfa'a-i Hukûk Cem iyeti

Hey’et-i Temsîliyesi Nâmına

Mustafâ Kemâl ${ }^{5}$

${ }^{5}$ TITTE Arşivi, Kutu No:306, Gömlek No:34, Belge No:34. 
MUSTAFA KEMAL PAŞA TARAFINDAN ALİ FUAD PAŞAYA.....

447

דיח

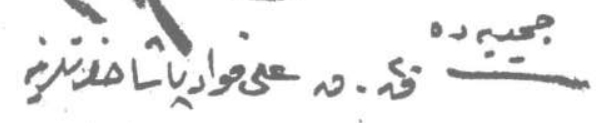

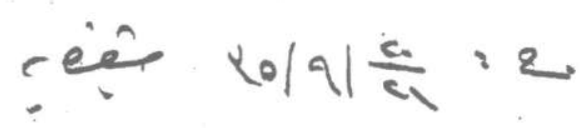

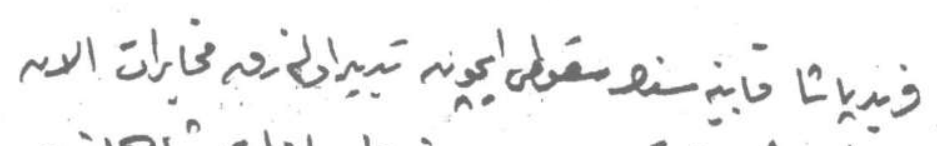

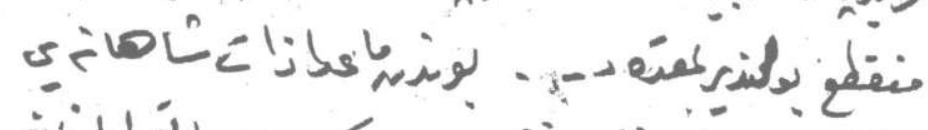

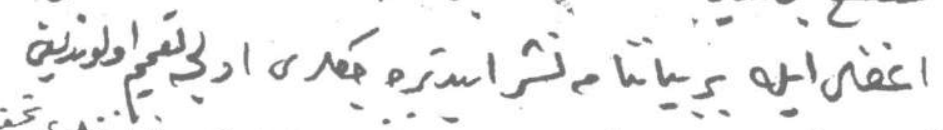

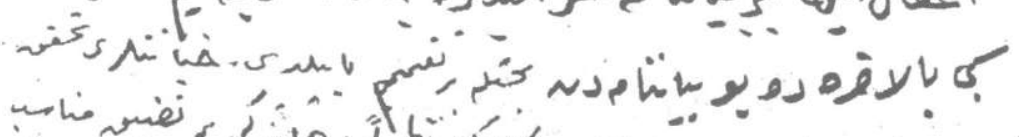

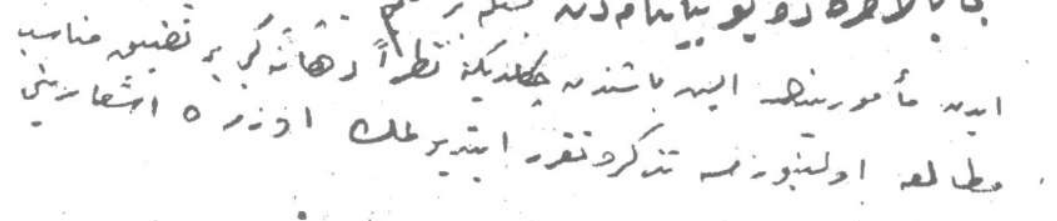

$$
\text { ivisine }
$$

raleno. 
Hamîdiye'de 20. K. K. 'Alî Fû̀âd Pâşâ Hazretlerine

\section{C.:20-21/9/35 şifreye}

Ferîd Pâşâ kâbînesinin sükûtu için tedbir olunarak muhâberât elân münkati' bulundurulmakdadır. Bundan mâ-'adâ zât-ı şâhâneyi igfâl ile bir beyânâme neşr ettirecekleri evvelce ta'mîm olunduğu gibi bil-âhire de bu beyânâmeden bahisle bir ta'mîm yapıldı. Hiyânetleri tahakkuk eden me 'mûrînin iş başından çekildiğine nazaran daha ne gibi bir tazyîk-i münâsib mütâla'a olunuyorsa tezkir ve takarrür ettirilmek üzere iş'ârını ricâ eyleriz.

Hey'et-i Temsîliye Nâmına

Mustafâ Kemâl

\section{K. Kumandanı}

Selâhaddîn ${ }^{6}$

\footnotetext{
${ }^{6}$ TITE Arşivi, Kutu No:306, Gömlek No:48, Belge No:48.
} 
MUSTAFA KEMAL PAŞA TARAFINDAN ALI FUAD PAŞAYA..... $\quad 449$

1

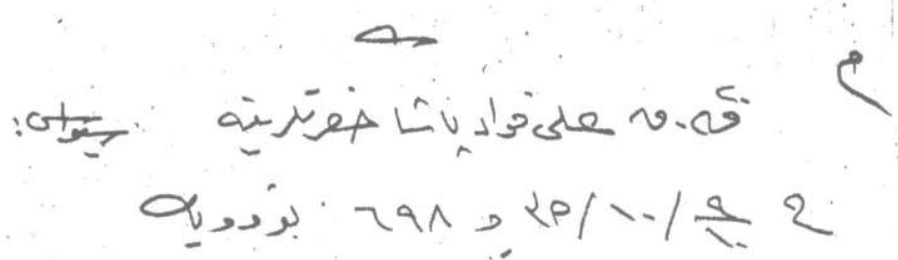

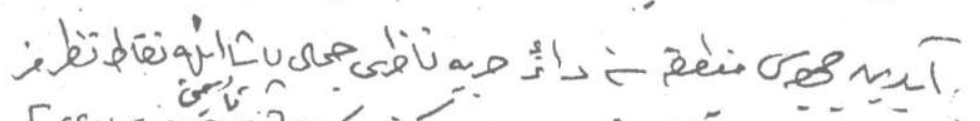

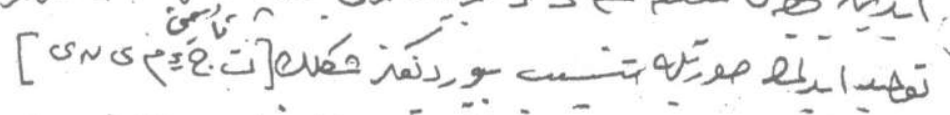

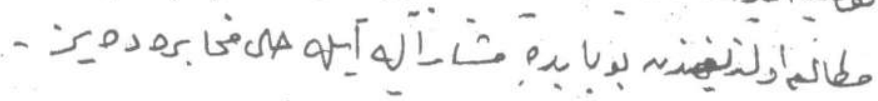

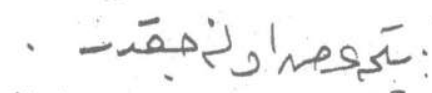

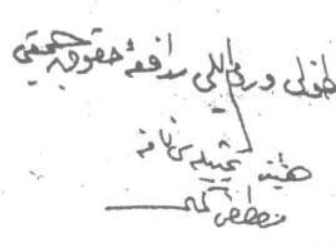

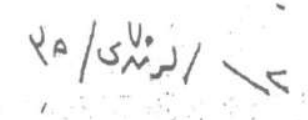

,

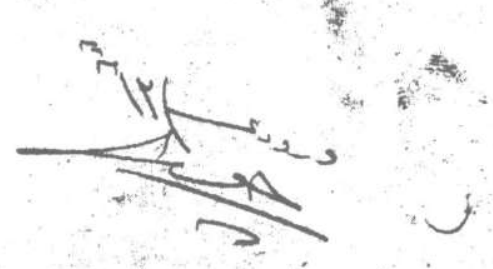


20. K. K. 'Alî Fû'âd Pâşâ Hazretlerine

Sivas

C. 9-10/10/35 ve 698 numroya

Aydın Cephesi mıntıkasına dâ`ir Harbiye Nâzırı Cemâl Pâşâ ile nikkât-i nazarımız tevhîd edilmek sûretiyle tensîb buyurduğunuz şeklin te 'mîni mütâla'a olunduğundan bu bâbda müşârun-ileyh ile hâl-i muhâberedeyiz.

Netice 'arz olunacaktır.

12 Teşrîn-i Sani 35

Vürûdu 13 minh

Anadolu ve Rûmeli Müdâfa'a-i Hukûk Cem 'iyeti

Hey`et-i Temsîlesi Nâmına

Mustafâ Kemâl ${ }^{7}$

${ }^{7}$ TİTE Arşivi, Kutu No:312, Gömlek No:55, Belge No:55. 


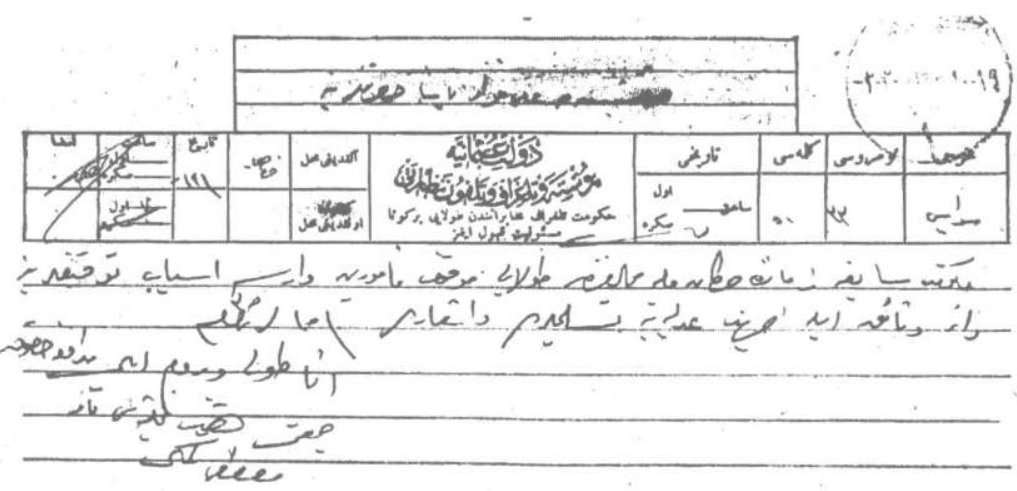


Telgrâf

Sivâs

'Alî Fû̀ âd Pâşâ Hazretlerine

Hükûmet-i sâbıka zamânında harekât-ı milliye muhâlefetten dolayı mevkûf me 'mûrîn varsa esbâb-ı tevkîflerine dâ'ir vesâ'ik ile cihet- $i$ 'adliyeye teslimleri ve iş'ârl.

15 Teşrîn-i Evvel 35

Anadolu ve Rûmeli Müdâfa'a-i Hukûk Cem 'iyeti

Hey`et-i Temsîlesi Nâmına

Mustafâ $\mathrm{Kemâl}^{8}$

${ }^{8}$ TİTE Arşivi, Kutu No:309, Gömlek No:27, Belge No:27. 


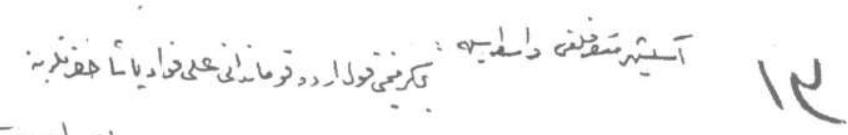

$$
\begin{aligned}
& \text { 世ᄂ। }
\end{aligned}
$$

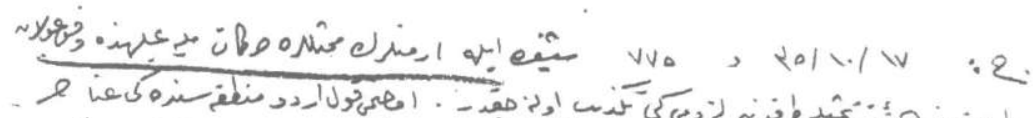

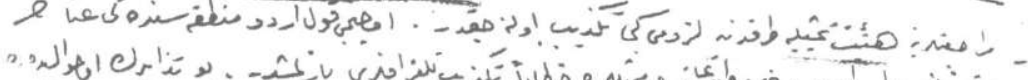

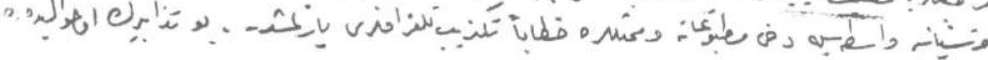

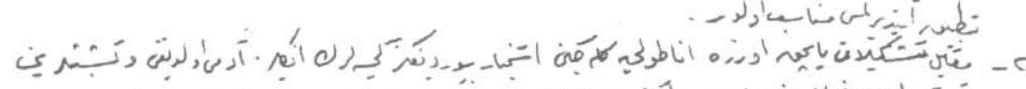
تَتِّاس

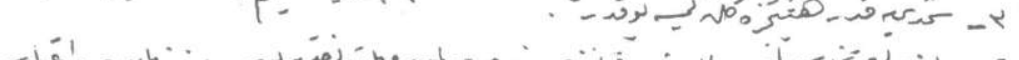

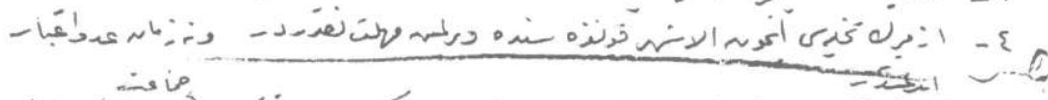

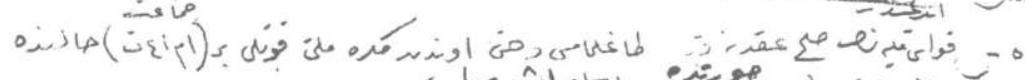

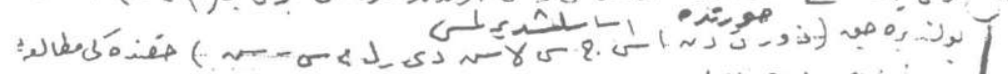

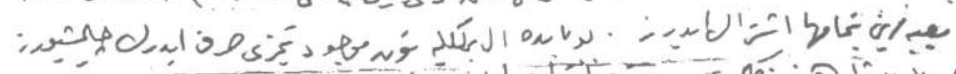

ricee

$$
\text { ? ? }
$$

रे J./ M

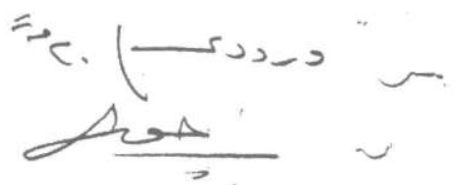


Amasya

Eskişehir Mutasarrıflığı vâsıtasıyla: 20. Kolordu Kumandanı 'Alî Fû̀âd Pâşâ Hazretlerine

C. 17/10/35 ve 775 şifre ile

1- Ermenîlerin mümessillere harekât-ı milliye 'aleyhinde vukû'bulan mürâca'atlarına hey'et-i temsîliye tarafindan lüzûmu gibi tekzîb olunacaktır. Üçüncü Kolordu mintıkasındaki 'anâsır-ı Hristiyâniye vâsıtasıyla dahî matbû'âta ve mümessillere hitâben tekzîb telgrâfları yazılmıştır. Bu tedâbîrin o havâlîde de tatbîk ettirilmesi münâsib olur.

2- Mukâbil teşkîlât yapmak üzere Anadolu'ya geleceğini istihbâr buyurduğunuz kimselerin İngiliz adamı olduğunu ve teşebbüslerini ta kîb eylemelerini lüzûmunu bil-'umûm merâkize teblî̆g ettik. Oraca bu teblî̆gin ta'mîm buyrulmasını ricâ ederiz.

3- Şimdiye kadar hey'etimize gelen kimse yoktur.

4- İzô̂r'in tahliyesi için Alaşehir Kongresi'nde verilmiş mühlet ne kadardır? Ve ne zamân 'add ü 'itibâr edilmiştir.

5-Kuvâ-yı Millîye'nin sulh 'akdine kadar dă̆ılmaması ve hatta ondan sonra milleti kuvvetli bir cemâ'at hâlinde bulunduracak sûrette esâslaşdırılması hakkındaki mütâla'a-i musîbelerini bi-tamâmihâ iştrâk ederiz. Bu bâbda elbirliğiyle bütün mevcûdiyetimizi sarf ederek çalışıyoruz. Sâlih Pâşâ henüz gelmedi. Takdîm-i ihtirâmât olunur.

Vürûdu 20 minh

Mustafâ Kemâl

5. Kafkas Fırkası Kumandanı

Cemîl Câhid ${ }^{9}$

${ }^{9}$ TİTE Arşivi, Kutu No:309, Gömlek No:23, Belge No:23. 
MUSTAFA KEMAL PAŞA TARAFINDAN ALI FUAD PAŞAYA..... $\quad 455$

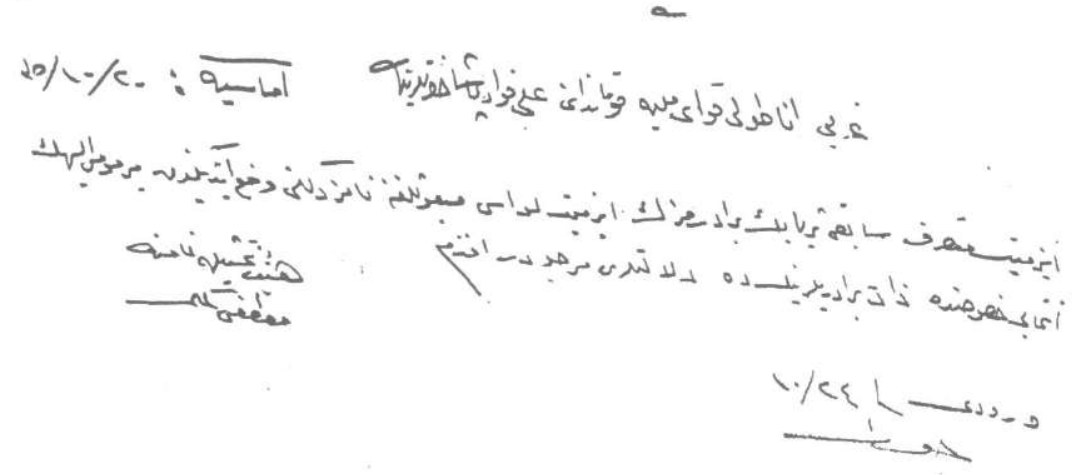


Amasya: 20/10/35

Garbî Anadolu Kuvâ-yı Millîye Kumandanı 'Alî Fû̀âd Pâşâ Hazretlerine

İzmît Mutasarrıf-ı Sâbıkı Süreyyâ Bey birâderimizin İzmît Livâsı meb' ûsluğuna nâmzedliğini vaz' ettiğinden mîr-i mûmâ-ileyhin intihâbı husûsunda zât-ı birâderlerinin de delâletleri mercûdur. Efendim.

Vürûdu 24/10

Hey'et-i Temsîle Nâmına

Mustafâ Kemâl ${ }^{10}$

${ }^{10}$ TITTE Arşivi, Kutu No:309, Gömlek No:67, Belge No:67. 
S'-

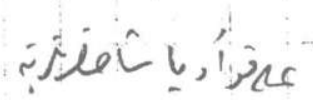

iveris

sticis

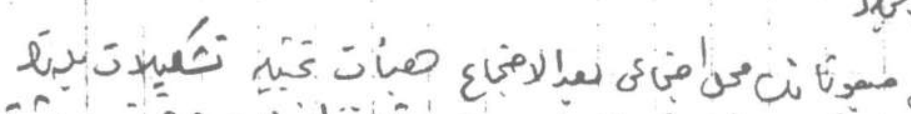

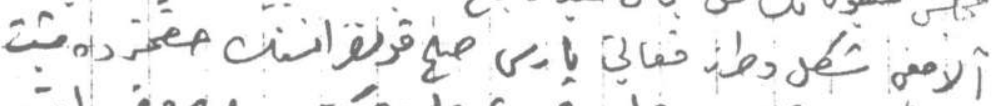

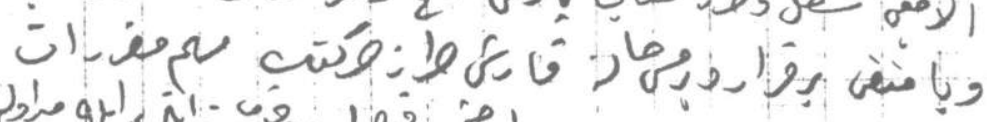

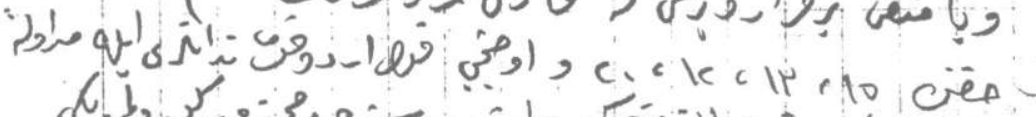

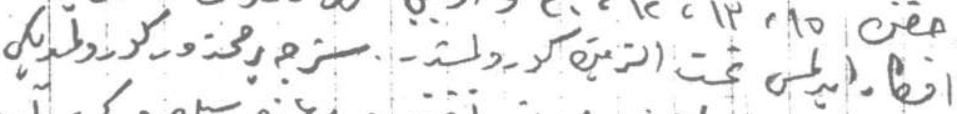
N火

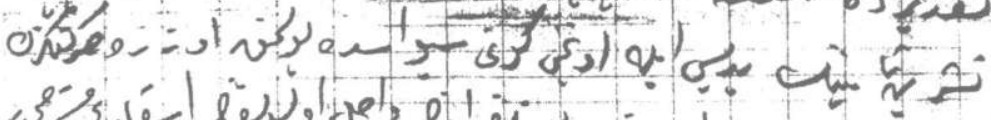

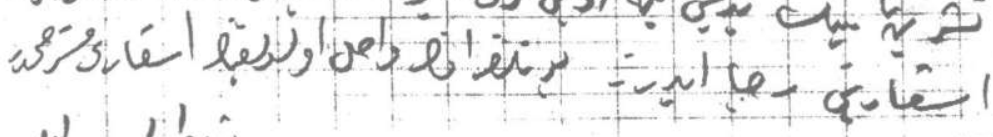
(j)

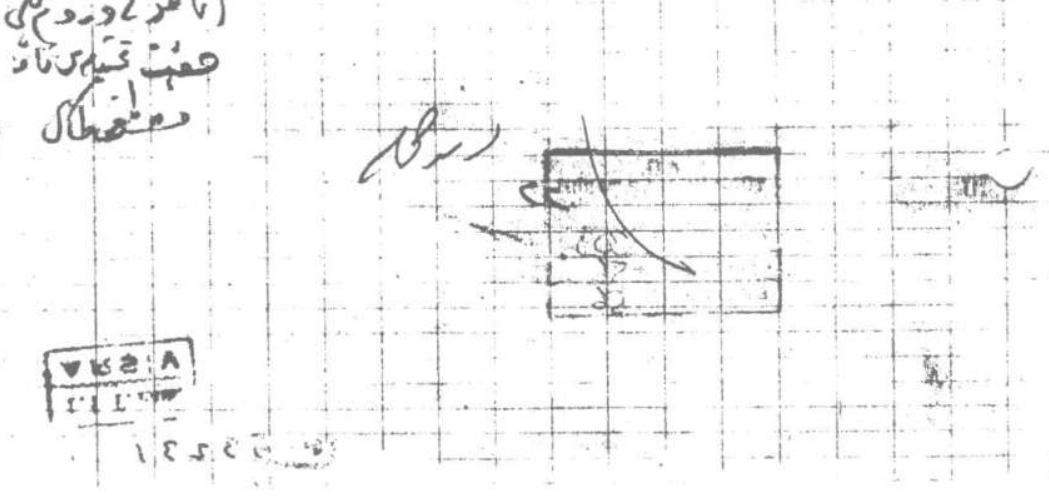


Zâta Mahsûsudur.

Gâyet 'Aceledir.

\section{'Alî Fû âd Pâşâ Hazretlerine}

Meclis-i Meb'ûsânın mahal-i içtimâ'ı ba'dü'l-içtimâ' hey'et-i temsîliye teşkîlât-l milliyenin alacağı şekil ve tarz-l fa'âliyeti Paris Sulh Konferânsı'nın hakkımızda müsbet veyâ menfî bir karar vermesi hâline karşı tarz-ı hareketin mühim mukarrerât hakkında 15, 13, 12, 20 ve Üçüncü Kolordu kumandanları ile müdâvele-i efkâr edilmesi taht-ı elzeminde görülmüş̧ür. Sizce bir mahzûr görü̈lmediği takdîrde mintıka-i 'âlîlerini teftî̧̧ bahânesiyle merkezden ayrllarak teşrîn-i sânînin yedisi ile üçüncü günü Sivâs'da bulunmak üzere hareketinizin iș ârını ricâ ederiz. Bu telgrâfın vâsıl olduğunun iş ârı müsterhamdır.

22 Teşrîn-i Evvel

Anadolu ve Rûmeli Müdâfa'a-i Hukûk Cem 'iyeti

Hey’et-i Temsîlesi Nâmına

Mustafâ Kemâl ${ }^{l}$

${ }^{11}$ TiTE Arşivi, Kutu No:309, Gömlek No:56, Belge No:56. 


\section{“ATATÜRK YOLU” DERGİSINDE YAYINLANACAK MAKALELER İÇIN BILGİ NOTU}

\section{Genel Kurallar}

1. Atatürk Yolu dergisi Mayıs 2002 tarihinden itibaren "Hakemli Dergi" statüsünde ve yılda iki kez (Mayıs-Kasım aylarında) yayımlanacaktır.

2. Dergiye gönderilen yazılar daha önce başka yerde yayımlanmamış veya yayımlanmak üzere aynı anda başka bir yere gönderilmemiş olmalıdır. Yazılar kabul edildiği andan itibaren "Atatürk Yolu" dergisi tüm yayın haklarına sahiptir.

3. Dergiye gönderilen yazılar, Danışma Kurulu tarafından ilk değerlendirilmesi yapıldıktan sonra hakemlere gönderilecek ve hakemden gelecek rapor doğrultusunda yazının basılmasına, hakem raporu doğrultusunda düzeltme istenmesine veya geri çevrilmesine karar verilecektir. Durum en kısa sürede yazarına bildirilecektir.

4. Derginin bir sayısına fazla yazı gelmesi durumunda yazarın da onayı alınarak yazı bir sonraki sayıda yayımlanabilecektir.

5. Yazılar iki kopya gönderilecek ve kopyaların birinde yazarın tanıtıcı bilgileri (unvan, kurum, haberleşme adresi telefon, belgegeçer) yer alacaktır.

6. Dergiye gönderilen yazılar (disketi ile birlikte) teslim alındıkdan sonra düzeltme için yazara geri gönderilmeyecektir. Çok fazla yazım yanlışı bulunan yazılar geri çevrilecektir.

7. Dergide yayımlanan yazıdan 20 adet tıpkıbasım ve 5 adet dergi yazara ücretsiz olarak gönderilecektir.

\section{ATATÜRK YOLU” Dergisi Yazı Formatı}

1. Türkçe makale başlığının altına özetin yazıldığı yabancı dildeki karşılı̆̆ı, makale yabancı dilde yazılmış ise Türkçe karşılığı yazılacak,

2. Makale adı ve yazar adından sonra 200'er kelimeyi geçmeyecek şekilde Türkçe özet "ÖZET" ve yabancı dilde özet “ABSTRACT" yazılacak,

3. Makale yazımında; (yazı tipi Times New Roman)

a) Başlık 14 punto koyu, yabancı karşılı̆̆ 13 punto normal ve her iki dilde de kelimelerin ilk harfleri büyük; yazar adı 12 punto koyu; Öz ve Abstract 10 
punto italik; metin 11 punto normal, dipnotlar 9 punto, kaynakca 10 punto yazılacak,

b) Metinde satır aralığı 1 (tek), paragraf başı boşlukları 0.5, dipnot başlangıçları 0.5 olacak,

c) Makale içindeki ana başlıklar metnin yazıldığı puntoda, boşluk bırakılmadan, koyu ve küçük harflerle yazılacak, alt başlıklar hiyerarşik bir yapı izlenerek oluşturulacak ve tek biçimlilik sağlanacak,

d) Dipnotlar aynı sayfa altında verilecek,

e) Dipnotlarda ve/veya kaynakçada yayın adları (kitaplarda kitap adı, makalelerde dergi adı) italik yazılacak, atıflarda alıntı yapılan sayfa numarası mutlaka belirtilecek,

f) Atıfta bulunulan kaynağın tam kimliği verilecek, atıfta bulunulmamış eserler verilerek kaynakca şişirilmeyecek,

g) Kaynakçada yazar adları küçük harflerle yazılacak,

h) Sayfa numarası altbilgi/üstbilgi kısmından verilecek,

i) Üstbilgi alanından çift numaralı sayfalara yazar adı, tek numaralı sayfalara makale adı 9 punto yazılacak

j) Her makalenin başlangıcında, makalenin kimlik bilgisi verilecek, (Örn. Ankara Üniversitesi Türk İnkılâp Tarihi Enstitüsü Atatürk Yolu Dergisi, S. 22, Kasım 1998, s. 1-10).

4. Ekler yazının sonunda verilecek ve altında belgenin içeriği hakkında kısa bir bilgi ile bilimsel kaynak gösterme ölçütlerine uygun bir şekilde kaynak yer alacaktır.

Haberlesme Adresi: Ankara Üniversitesi Türk Inkalâp Tarihi Enstitüsü

Gıda Mühendisliği 4 nolu bina zemin kat No. $2 / 4$

06280 Keçiören / ANKARA

Tel: (0312) $3604013 \quad$ Belgegeçer: (0312) 3594308 